\title{
Thelma and Louise do Religious Education: A Dialogue from the Edge for Leading with Hope \\ Patty Meyers \& Susan Willhauck
}

\begin{abstract}
The 1991 movie Thelma and Louise and its protagonists continue to be cultural icons for many women of all ages. With quotes, song lyrics, the metaphor of living on the edge from the film and collected wisdom from pedagogy, two religious educators reflect on their vocation and leadership in a dialogue that draws implications for the teaching ministry. The themes highlighted address friendship, the journey, risk-taking, awakening, turning points, and the choice to keep going no matter what. The authors believe that their friendship and co-creating dialogue offer their students hopeful models of leadership through their conversations about their vocations in ministry and higher education. Further, the way that they share ideas and experiences are good for their students and themselves.
\end{abstract}

\section{INTRODUCTION}

In his 1998 seminal work, The Courage to Teach: Exploring the Inner Landscape of a Teacher's Life, Parker Palmer lifts up courage as a necessary quality for teachers. The book's cover photograph depicts a high and formidable cliff with a treacherous edge. One could say that those who teach and those who learn stand on the edge between the known and unknown, and it takes a kind of courage to stand on that edge. The movie Thelma and Louise (MGM Studios Production 1991) came out just over a decade ago and its protagonists became pop icons for women friends. It should not, however, be stereotyped as a mere "chick flick," since its message and appeal is much broader. When confronted with abuse and a life-threatening situation, Thelma and Louise decide to live their lives "full throttle." The strength of their friendship and a belief that life has to be better somewhere propels them into a cross-country road trip. The last scenes of the film portray the two friends surrounded by seemingly insurmountable odds and on the edge of the unknown. Though the situation seems desperate, they remain positive. They hold hands and say, "Let's keep going."

We do not want to push the analogy too far because the film ends with a "freeze frame" of their car in mid-air and a Grand Canyon cliff in the background. We do not anticipate that kind of ending, but we believe that we can learn from Thelma and Louise. We do not extol the violence in the film, but look beyond it to find deeper meanings and valuable theological and pedagogical insights in this Academy award winning film. In a world that sometimes lacks hope, teaching is an adventure that takes us into unknown territories. Both of our lives and our teaching are enriched by strong friendship. We hope that we do not end up going over the cliff, but we acknowledge that, as we live out our calls to ministry in higher education, we cross over a sacred edge where learning takes place. 
In their book, The Women who Broke all the Rules, Susan B. Evans and Joan P. Avis describe women of our generation as "accidental pioneers" who choose to deviate from the accepted patterns of college, marriage, and raising a "Beaver Cleaver" family $(1999,3)$. This generation of women learns to survive and thrive by initiating, originating, breaking new ground, and "going where no man has gone before" (with thanks to another show, Star Trek). Thelma and Louise, like other women of our generation, find themselves to be "accidental pioneers" as they leave the relative security of the known to venture into the unknown.

In this paper, we stand on the edge of accepted professional and vocational practice and choose to go where few decide to go: into a vocational dialogue that encourages educators to lead with hope. Using quotes and song lyrics from the film and collected wisdom from pedagogy, we engage in a dialogue drawing parallels for teaching in both graduate and undergraduate religious education programs. In doing so, we will also reflect on our friendship and vocations as educational ministers. One of the lessons Thelma and Louise teach us is that we are stronger and more effective when we do things together. This paper grew out of our friendship and ongoing dialogue about our vocations. Though formatted as an essay, the entire document was created in dialogue that we hope will contribute to an understanding of the religious education vocation.

"Part of You, Part of Me" (song from the soundtrack, Written by Glenn Frey \& Jack Tempchin. Performed by Glenn Frey. MCA Records)

Thelma: "You're a good friend." Louise: "You, too. You're the best." Women's Friendship as a Resource for Leading with Hope

Thelma and Louise, like many friends and couples, epitomize the adage, "Opposites attract." Blonde Thelma is a bit younger than redheaded Louise, often careless and disorganized to the point of sloppiness. Louise is more mature but a bit cynical and uptight. However, Thelma and Louise's friendship not only holds them together through good times and bad, it gives each of them courage to keep going. In the film, the two friends take turns encouraging the other as situations require, and both grow with the help of the other.

Kahlil Gibran said that, "Friendship is always a sweet responsibility, never an opportunity" (Chittister 2000, 25). Thelma and Louise exemplify this sweet responsibility as they take care of each other. They work at their relationship and never take it for granted. Joan Chittister quotes Gibran to begin her chapter on Phoebe in The Friendship of Women: A Spiritual Tradition. She refers to Phoebe as one who offers support in hard times. Phoebe receives only two lines in the Christian scriptures that describe her as deacon, friend, and benefactor. Her friendship is important to Paul, and some scholars believe that she delivered Paul's letter to the Romans. She gives her wealth, time and service for the sake of supporting others' dreams. Chittister says that the Phoebes of life hold the world together $(2000,27)$. Phoebes are self-contained, but not self-centered women who remind us that we are to be about more than ourselves. 
We are to be conscious of the needs of others. As the song from the soundtrack says, and as Paul wrote to the Corinthians, we are part of one another. (See 1 Corinthians 12 in the Christian Bible.)

Phoebes make the world a better place in several ways. One of the chief means is through hospitality. The hospitality inherent in the church potluck supper, famous or infamous in our faith tradition, is a metaphor for teaching for Patty. The host of the potluck supper sets the table and invites people to it. Everyone brings something to the table, and everyone takes what appeals to them and nourishes them. Host and guests share in mutual edification and compassion. Parker Palmer eloquently makes the connection between hospitality and teaching with hope when he writes:

good teaching is an act of hospitality... and hospitality

is always an act that benefits the host even more than the

guest. The concept of hospitality arose in ancient times when

this reciprocity was easier to see: in nomadic cultures, the food

and shelter one gave to a stranger yesterday is the

food and shelter one hopes to receive from a stranger

tomorrow. By offering hospitality, one participates

in the endless reweaving of a social fabric on which

all can depend-thus the gift of sustenance for the guest

because a gift of hope for the host. It is that way in teaching

as well: the teacher's hospitality to the student results in a world

more hospitable to the teacher $(1998,50)$.

Phoebe models witness and service. As a deacon of the church, she does not efface herself nor deny the obligation to be fully oneself while serving others. Chittister says that the "Phoebe factor in friendship reminds us that we are... raised up to be cocreators of the cosmos we call life" $(2000,28)$.

Friends often embody a theology of co-creation. It is our experience that creating something together makes both the individuals and the product of our efforts better, involving us in God's creative activity. It also portrays an assumption that religious education is an intentional communal enterprise and teaching is an act of co-creating as writing this paper has been. Psychologist Rollo May defines creativity as both the process of making and bringing into being and the way that we express our being $(1975,32-33)$. As we engage the world, we both change it and are changed by it. Such engagement implies that we break through old patterns of consciousness and we are never the same afterward.

Some research by Taylor, Klein et al. shows that the friendship of women enhances their ability to deal with stress (2000, 411-429). Another study from the Harvard Medical School called the Nurses' Health Study finds that women friends help each other to live longer, more joyful lives, and conversely, that the lack of close confidantes is detrimental to health (Michael 2000, 5). If not for each other, neither Thelma nor Louise would survive all the situations they encounter in the film. They become better and stronger because of their friendship. Friendship helps women who live on the edge to maintain high levels of physical and mental health. 
Friendship is a sweet responsibility and it enhances teaching. Indeed, teaching is an act of friendship. Maria Montessori said that teaching is "practicing the great art of companionship" in order to draw out the potential within and to lead others to grow in "responsible freedom and boundless creativity" (Groome 1998, 39).

We have been friends for eight years. We met at a meeting of the United Methodist Association of Scholars of Christian Education (UMASCE) and like Thelma and Louise, we are opposite in many ways. We believe friendship is essential for the vocation of religious education because friendship helps to engender hope in our teaching. Like Phoebe we are both deacons and see ourselves as living for others, as "deliverers" and as agents of hospitality in our teaching. We have both benefited from the friendship of colleagues and mentors in the field of religious education. With gratitude, we particularly acknowledge Helen Archibald, Kate Dooley, Dorothy Jean Furnish, Rosemary Skinner Keller, Nelle Slater, Linda Jane Vogel, and each other. These women friends are resources for teaching and leading with hope.

\section{Louise: "You get what you settle for"... "It's not your fault." Educational Leaders Refuse to Settle}

These quotes appear at the beginning and end of the film respectively. The film follows the snowballing effect of abuse and how it propels Thelma and Louise into a different world. It leads them to reject gender roles they had previously accepted, to face power struggles, murder, armed robbery, destruction of property and the end of their world as they knew it. At one point the local police investigator, Slocum, says sympathetically to Louise, "I know what's making you run." Both women had been raped. Though abused by men, they decide not to settle for lives of regret and pain. It was not their fault that they were raped and they journey toward freedom from settling and from the constraints of their existence.

In the United States, one-third of the population has grown up in abusive homes. Recent research indicates that as many as 85 percent of children who were abused grow up to abuse others (Friedrich 1997, 17). The cycle of violence continues to revisit future generations. Though Thelma and Louise decide neither to settle nor to accept blame for the abuse that they both experienced; they had been vulnerable, easy targets for it. It has always been difficult to escape this cycle of violence. Many of our students have experienced this abuse. Leading and teaching for hope involves helping people know that they do not have to settle and that God wants them to be whole and healthy.

Like Thelma and Louise, Parker Palmer says that teachers are easy targets because they are often powerless to strike back $(1998,3)$. Teachers risk being "easy targets" when they create the conditions that help students and themselves to grow. Many teachers know the feeling of vulnerability that accompanies the risk-taking that is an integral part of the teaching vocation. We will mention only a few forms of this risktaking here.

Not following the established rules or political protocol explicit or implicit in the academy and the profession makes teachers vulnerable. For example, grade inflation is a "hot-button" ethical dilemma because grades often relate to professors' popularity, 
student evaluations, performance evaluations, numbers of students in classes, courses and contracts offered. Do we settle for mediocrity in order to keep our jobs? Do we enforce institutional policies if lower enrollment is a consequence? Sharing our personal stories with students can be risky, as well as having students risk sharing their own personal stories in the classroom. Do we risk being authentically liberal if we teach in a theologically and politically conservative institution or vice versa? Parker Palmer talks about living an undivided life, of being true to ourselves, refusing to give in to the forces that make us conform to conventional practices $(1998,167)$. He describes the dangerous intersection of public and private where teachers stand every time they enter a classroom $(1998,17)$.

Educational leaders refuse to settle even if they feel vulnerable. We do not settle when we decide to accept our calls to the vocation of teaching. We risk vulnerability when we decide to buck institutional power struggles to maintain our integrity and dignity. Fear is a powerful and ever-present "guest" in education. Both teachers and students fear they will not be valued by the other. A culture of fear threatens our vocation. In The Courage to Teach, Palmer acknowledges the risks that teachers and students take when they venture forth together. Every epistemology tends to become a question of ethics and power. Palmer explores the distance between the knower and the known and warns that when the distance is too great, we risk killing each other off as irrelevant (Feb. 4, 1998, Lecture). Any attempt to reach across the distance requires that teachers give of themselves. Teachers risk settling when they try to reach students without being authentically who they are. In our teaching we are mindful of Tex Sample's warning, "It is not enough to reach people, Hitler reached people" $(1990,5)$. Teaching and learning is a communal enterprise and we cannot risk settling for being less than true to ourselves and our calls.

\section{Louise: "How do you like the vacation so far?" Vacation/Vocation in Religious Education}

When Thelma and Louise first start on their trip, they plan to go fishing in the mountains, a brief reprieve for an overworked waitress and a neglected housewife. "I just want to have some fun," Thelma says as she persuades Louise to stop at a rowdy bar. "Is this my vacation or isn't it? You said that we were going to get away and let our hair down. Well, darlin', my hair is coming down." The word vacation is one letter away from vocation. Vacation is from the Latin vacca, to empty, and its root is very similar to that for the word vocation, vocare or voice. Vacations are times to empty ourselves of stresses, worries and burdens. While on vacation, we cease doing our normal work in order to recreate. Vocation, on the other hand, is what we do with our lives when we listen to the call within to do what gives our lives meaning and value. Theologically speaking, vocation is a call from God to live our lives engaged in work and play that will further God's vision for all creation. As Parker Palmer says, vocation is not so much "a goal I pursue, but a calling that I hear." He repeats an old Quaker saying, "let your life speak." (2000, 4). 
Christian vocation is the call that comes from being made new in Christ, a call to all baptized Christians to faith and discipleship, to do God's work in the world and in the church. The Bible is replete with "call stories." God's personal and collective summonses are some of the best-loved stories in all the biblical material. There is a sacredness to work, whatever kind of work it is, if God needs it done and it contributes positively to the world. According to James Fowler, it is partnership with God $(1984,95)$. Vocation, however, is often thought to be one's chosen career, one that is chosen for you as in "one's lot in life" rather than what is chosen for you by God. Relatively few people hear and accept the call to the vocation of religious education, but those who do step forth in an act of hope to let their lives speak in their teaching. It is a vocation, a field that chooses us, that speaks to us and sheds light on our identity (Palmer 1998, 25).

Some people in the world, however, look at teaching as escapism, as avoiding "the real world," hence the adage, "Those who can, do, those who can't, teach." There is a hint of escapism in the film, or more accurately, a sense of adventure. Teaching is, in some measure, time apart from the world. The classroom is a laboratory and a space for thinking about what one does and will do. Many educators reverse the adage to "Those who can, teach." When teaching takes on the character of an adventure, a foray into subject matter, it is indeed fun. Thelma and Louise's vacation does not go as planned. They get sidetracked into a vocation of sorts. We could say that they discover their true vocation while on vacation. Their vocation is not so much to a life of crime as it is a call to break free from their lives of drudgery, from what Thelma calls "the sedate." They become "accidental pioneers." After Thelma robs a store, Louise asks her, "Have you found your true calling?" "Maybe," replies Thelma, "the call of the wild!"

Things go from bad to worse for the friends, but when one becomes weak, the other picks up the slack and grows stronger. Later in the movie, when they are on their way to Mexico after barely outrunning the law, Louise reflects on the adventure and asks Thelma, "How do you like your vacation so far?" "I guess I went a little crazy," Thelma says. "No, you've always been crazy, you've just never had a chance to express yourself before," responds Louise. An attempt to temporarily escape the sedate ultimately gives rise to her true self-expression. Discovering our vocations gives us confidence to try new things, to risk losing some things and to find new outlets for selfexpression.

\section{Louise: "We've just got to figure out what we're going to do next." Educational Leadership is a Journey}

The Japanese proverb, "the journey is the destination" has become almost a cliché, but this movie demonstrates its truth. The film, Thelma and Louise, often compared with Butch Cassidy and the Sundance Kid, is a classic road story with some twists. The two women also embark on inner journeys and experience personal transformation. Louise panics after she shoots the man who raped Thelma, but reassigns herself to "figure out what to do next." She and Thelma get into a series of dilemmas. With each turn of events, they get into deeper trouble, but they continue to 
find ways to cope. At one point on the road they stay at the Vagabond Motel. By the end of the film, Thelma matures and Louise "loosens up" in a kind of role reversal. Parker Palmer describes the transformation that pilgrimage can bring:

In the tradition of pilgrimage, those hardships are not seen as accidental but as integral to the journey itself. Treacherous terrain, bad weather, taking a fall, getting lost - challenges of that sort, largely beyond our control, can strip the ego of the illusion that it is in charge and make space for true self to emerge $(2000,18)$.

As women of the baby boomer generation in higher education, we both have learned, as Susan Evans and Joan Avis say, to overcome detours and obstacles, to cope creatively with life events, and to take risks in love and work. "Women of all ages have now come to accept transition and personal change as integral parts of life" (1999, 88). This goes for teaching as well as life.

Teaching is, of course, also a journey. With each turn of events, Thelma and Louise have to improvise and figure out what to do next. Our vocation requires that we do the same. Jazz improvisation is an appropriate metaphor for the times when we are really "groovin" in the classroom, when we lose ourselves in the subject. Improvisation involves intuitively knowing the right notes to play without a printed score. Artists figure out what to do next as they go along. The notes go sour when we play the wrong chord. When we "get into trouble," the only way out according to Parker Palmer, is to "go deeper in." It is to "enter, not evade, the tangles of teaching so we can understand them better and negotiate them with more grace" $(1998,2)$. We teach with an end in mind, but sometimes it is a mystery how we will get there. We just have to put one foot in front of the other and find our way.

Teaching is an ongoing process that is never quite finished. No one has mastered it all so there is always more to teach; there are always new paths to take on the journey. When Thelma and Louise come to what looks like the end of the road, they hold hands and keep going. The challenges of the teaching journey may cause us to lose heart. We may not always be able to readily see the fruits of our labor. As one teacher says, "I once had a job mopping floors. It was very gratifying because I could immediately see the difference I had made. That is not always the case with teaching" (Willhauck 2001, 13). We may not always be able to "turn the soul," as Plato put it, but we keep going (Groome 1998, 37). We know that the journey may hold surprises and the unspeakable joy that accompanies learning. We know that our vocation as Thomas Groome says, is "long term". We must take the "long view in order to stay the course" $(1998,442)$.

Teachers always keep moving. We embody the negotiation of Erikson's crisis of generativity versus stagnation. We cannot let those fears that Palmer names paralyze us. Fortunately we do not have to go this road alone. We walk with each other and with God. Maria Harris compares the journey of teaching to Anne Sexton's poem, The Awful Rowing Toward God: 
We cannot say a word, we cannot read a text, we cannot write an essay without trying to walk to God. Without trying to touch God, even if we are not aware of the walking, the touching $(1988,12)$.

We have what Groome calls an abiding faith:

Faith in the worthwhileness of [our] vocation, faith in the potential of learners, and faith in Gracious Mystery that is ground and horizon of all $(1998,36)$.

\section{Thelma: "Something's crossed over in me. I can't go back." Turning Points in Vocation}

Every journey has twists and turns, and there may come a point in all our lives when we realize that we have changed, and like Thelma, realize that something has crossed over in us. We may not be conscious of it until we look back on the road we have traveled to this point in time and space, but we recognize that we are no longer the same. Developmentalists talk about turning points and crises that project us into a new level of personhood or faith. However, Ellen Goodman writes that those crises may not really be predictable or universal across time and cultures $(1979,5)$. Change and crises come both accidentally and by our own volition. We name them as turning points in our life and vocation because they turn our life into something else, perhaps into our true selves. At this point in our dialogue, we speak personally about some of the moments when that something had crossed over in our vocational lives.

\section{Susan writes:}

I cannot remember the exact moment when I fell in love with learning. I do remember one turning point that occurred when I was in the fourth grade. On the first day of school, my teacher issued each child in the class a brand new geography textbook with large, golden, beautiful letters, Adventures in Learning. I loved that book! I thought that it was the most wonderful book in the world (other than the Bible, which I had received from my church in the third grade). This book had marvelous pictures from all over the world. It set my imagination in motion, taking me to the farthest points on the globe, all while sitting in an old wooden school desk in a small town North Carolina public school. Our young and vivacious teacher was our tour guide, showing worlds of which I had never dreamed. I knew I wanted to do that. I knew I wanted to be like her.

One of the greatest gifts my father ever gave me was a box full of left over office supplies and paper scraps when I was six years old. He had cleaned out his desk at work, and what most people would throw away, he transformed into a wonderful gift. You see, my father knew that I loved to play school. He knew that I had invented my own classroom, and that I was "Miss Scott," the teacher. He had seen me line up my dolls and stuffed animals to be my "students." On that big box of pens, lead pencils, 
stenography pads, old accounting ledgers, rulers and templates, my dad wrote, "The Miss Scott Kit." I loved it! As my alter ego, I practiced what I had seen my own teachers do. I created class rolls on those accounting ledgers. I gave grades and assignments. A psychoanalyst might have a hey-day with this, but I have always wanted to be a teacher. Today as a seminary professor, I am still "playing school." I take it very seriously, and I get paid for it, but I love my work and I see it as playing, not in the sense of performing, or acting, but in the sense of doing something I really enjoy, something that gives me great joy. Everyone should love his or her work this much. It has been said that if work feels like play, one is in the right vocation.

I went through college and seminary soaking up as much theology as I could. I longed to teach in higher education. I felt something urging me to do so. I also wanted it all-to be married and have a family. I always thought of it as a goal to pursue, but as Parker Palmer says, vocation comes more from listening to your life, letting your life speak. Many doors opened for me. I got a fellowship to go into a Ph.D. program at Catholic University. When my first child was three months old, I dove headfirst into that program, classes, papers, reading and changing diapers. Looking back, I ask myself, "Was I out of my mind to do that? Did I sacrifice my daughter's well-being?" Now a college sophomore, she seems to have survived. In fact, she jokes that because I often took her with me to class in a baby backpack, that she should have the degree. Then, however, some doors began to close for me. I think I expected the world to bow at my feet. Parker Palmer refers to it as "way closing" $(2000,38)$. He says that we learn as much from "way closing" behind us as we do from a way opening in front of us. These were difficult times for me, yet I learned that I could not control life just by my own efforts. I began to listen to my life. There were some things I needed to learn, and I learned them by being engaged in various ministries. Then came a turning point. For some unknown reason, the dean of my seminary asked me to teach. It started out as teaching a course here and there. Soon it evolved into a full-time position. I count it as nothing short of a miracle that this person gave me a chance. It was pure grace.

\section{Patty writes:}

As the oldest of six siblings, I started teaching when my first brother was born. When I was a child, I loved church, school and I loved to read. I played school and church with my sisters and brothers as the sometimes unwilling students in my class. I read everything I could. I read the dictionary and the encyclopedia. I kept a flashlight under my pillow to read after my parents put me to bed at night. I even figured out how to break into the cabinet where my dad kept his "dirty" books and read them, too. My mother dedicated my life to God while I was in her womb, and raised me to become a Salvation Army officer. I participated fully in the church by playing the piano, singing in choirs, and going to Sunday School. I started teaching Vacation Bible School at age fourteen. I was seventeen years old before I realized that my mother's call to ministry was not my own. While attending a future officer's weekend at the Chicago Salvation Army Training College, I realized that I was in the wrong place. I was not called to that ministry. I fled that confused call by marrying my high school sweetheart, going to college and teaching public school music for four years. 
Ironically, a major fight with my spouse propelled me to attend Garrett Evangelical Theological Seminary. As when I first became a United Methodist, I felt as though I had come home. I started to become the person I am today. I grew from a confused "door mat" with no self esteem to knowing for sure that I was called to educational ministry.

Many years later, after working in the church as a Director of Christian Education and music, and teaching in a Roman Catholic university in Portland, Oregon for twelve years, I hit the "stained glass ceiling" and felt as though I was dying. I had been divorced, then married a man whose office is in Portland, so I never seriously considered relocating. I was unhappy and unfulfilled. While attending the APRRE meeting in Atlanta in 2000 , I had a nightmare that convinced me that I had to leave that university even if it meant that I no longer taught. Like Thelma in the film, "something crossed over in me" and I knew that I could not stay there. Shortly after my return from Atlanta, I received a call from Dr. Ed Trimmer, Head of the School of Religion and Christian Education at Pfeiffer University. To shorten the story, I now chair the Department of Christian Education and Youth Ministry at Pfeiffer University. I acknowledge with gratitude the support of women friends especially during hard times.

\section{Thelma: "I don't ever remember feeling this awake...I never felt this awake before." Vocational Awakening}

Somewhere on the road in the desert, as the sun rises high over the mesas, Thelma says to Louise, "I don't ever remember feeling this awake." Carol Gilligan describes the experience of awakening in women's development $(1982,8)$. It is coming into one's own, a religious experience of heightened consciousness. It is knowing what you are meant to be and do. It may come at any time in a woman's life or never. In Women and Teaching, Maria Harris says, "learning can lead to the revelation of oneself." This revelation is an awakening, a self-discovery, a satori. She describes it:

I believe that Revelation occurring in the context of teaching is precisely this: self-discovery; self-understanding; self-possession in a community of free and authentic selves. Revelation is the realization of deliverance by the Mystery of God, but of ourselves to ourselves in communion with all that is $(1988,67,69)$.

When we are awake we actively look forward. When we find our true vocation, we do feel more awake, energized and spirited. Parker Palmer expresses such an awakening as an experience of awareness of the moment:

Disabused of our illusions by much travel and travail, we awaken one day to find that the sacred center is here 
and now-in every moment of the journey, everywhere in the world around us, and deep within our own hearts $(2000,18)$.

Thelma and Louise experience such an awakening moment. Teachers awaken to this sacred joy when we lose ourselves in our work. We realize we are doing what we are meant to do. We awaken to the reverence of all of life, to wake up from sedate sleep, able to see and help others to see the extraordinary in the ordinary. No longer do we go through life "just going through the motions." According to Allen J. Moore, when one answers the call to teach, when one does that which she or he really loves, the act itself takes on a sacredness $(1991,158)$. As Pearl Buck reportedly said in an unpublished speech:

Only the brave should teach...Teaching is a vocation.

It is as sacred as priesthood; as innate a desire, as inescapable as the genius which compels a great artist. If one has not the concern for humanity, the love of living creatures, the vision of the priest and the artist, one must not teach.

Like Alfred North Whitehead, Moore affirms that teaching includes a reverence for the whole of life. That reverence means that the teacher is not simply held in awe by his or her students, but that reverences draws others into it, into an awakening (Moore 1991, 158-159). vocation:

A poem In Practicing God's Presence, expresses the sacred joy of one's true

Keep your dreams alive.

Do what you want to do.

Whatever is your heart's dearest desire

Is God's gift of joy to you

(Meyers, 1994, 8).

Christians profess that Jesus came that we might have abundant life, but many people have a hard time figuring out how to experience that abundance. We believe that a significant piece of that puzzle is discovering what gives them joy. We often ask our students, "What do you love to do so much that you lose track of time when you do it?" Their answers often lead them to know what God calls them to do with their lives.

\section{Song: "The way you do the things you do" (The Temptations) How We Live Out our Vocations}

"You could have been anything that you wanted to...the way you do the things you do!" The song blares from the car radio and encourages the women to keep going as they drive down the road to an unknown future. In similar ways we gain confidence 
as teachers as we reflect and dialogue on our call. We, too, are thrust toward the unknown as we challenge each other to do more and be more in our educational ministry. What propels someone into the teaching life, for teaching truly is not just a job; it is a way of life. It is something different for each of us.

\section{Patty writes:}

Somewhat like Thelma and Louise, I have traveled far from the edge of despair with good friends. I have learned many things along the way, and congruent with the research cited earlier, I am happier and healthier. Today I joyfully live out my call to educational ministry at Pfeiffer University, teaching both graduate and undergraduate students. As a United Methodist Deacon in Full Connection, I am appointed by the bishop of the Portland area to serve in the Western North Carolina Annual Conference of The United Methodist Church. I love to "live the questions" with students, as Rainer Maria Rilke put it. I love the privilege and holy responsibility of being a lifelong learner with them. I am blessed to be married to a man who loves God and the church as much as I do, and who fulfills his own call to ministry as a lay person working in finance and administration. We gratefully acknowledge that two vows are at work: our marriage and ordination vows, and we are committed to God, each other, and the church. I am grateful that my vocation combines the essence of my childhood games of playing church and school. I am truly doing what I love and am called to do.

\section{Susan writes:}

Every day I listen to my life and thank God for the supreme privilege and honor of being able to walk just a little way with my students along their journey. Yes, I spent so much money on my education that I could have been a neurosurgeon, or I could have been this or that, but, the real story is that, no, I could not have been any of those things, for I am called to teach. A colleague of mine tells his students considering the ministry, "If there is anything else in the world that you think you can do besides the ministry, you ought to do it." If you are called to the ministry, you cannot do anything else.

When things do not go so well, and I start to question my call, something happens to re-awaken it within me. Sometimes I glimpse eyes alight with recognition or a student expresses gratitude for my support or acknowledges that I have challenged him or her. Sometimes I have that sense of being on the edge with my students. Maria Harris told the story of Annie Sullivan teaching Helen Keller and tapping the letters w-at-e-r into her hand, convinced that she has the capacity to learn. I will always remember the poem of Christopher Logue that Maria Harris shares:

Come to the edge.

It's too high.

Come to the edge.

We might fall. 
COME TO THE EDGE.

And they came.

And she pushed them.

And they flew $(1988,72)$.

Sometimes I sense the grace of God working through me or despite me. I travel down this road I have chosen (or that chooses me) and it is only God's grace that saves me. I am coming to realize that teaching is not so much about a good performance on my part, but truthfully living my vocation.

\section{Thelma: "Let's keep going!" Summary}

In this paper, we travel with Thelma and Louise in order to learn something about leading with hope. Some who view the film could see it as nihilistic. We choose to see the ending as hopeful rather than despairing, as leaping into the unknown rather than giving up. Thelma and Louise keep going into the unknown. We acknowledge the women who have gone before us, blazing trails that make it possible for us to fulfill our callings in educational ministry today. Previously we named women who have been role models for us, including the New Testament Christian model of Phoebe. Through this dialogue we hope to encourage others to go where there is no path, willing to live and teach on the edge with courage rather than fear and a sense of futility.

Together we decide to live on the edge of our profession as we engage in this dialogue. Speaking dialogically goes against the grain of power struggles and one-upman-ship that is too often found in the academy. We choose to be friends, pool our knowledge, question our assumptions, and to model going into the unknown together. What does the future hold for the "Thelma and Louise" of APRRE? The film ends with the two friends flying through mid-air in a 1966 green Thunderbird and leaves the viewer to choose where the journey will take them next. With our sunglasses on to allow us to see clearly and ward off any glares, we choose to do our educational ministry in a spirit of faithfulness, mutuality, respect and fun. We believe that by holding hands and cocreating, we offer our students hopeful and positive models of leadership. We acknowledge our vulnerability and the reality of hard things in life, but we reserve the right not to settle. We invite our students and colleagues to join us on the edge and say, "Let's keep going!" 


\section{References}

"Thelma \& Louise" MGM/UA. (c) 1991. MGM Pathe Communications.

Chittister, Joan. 2000. The Friendship of Women: a Spiritual Tradition. Erie, PA: Benetvision.

Evans, S. B., and J.P. Avis. 1999. The Women Who Broke All the Rules: How the Choices of a Generation Changed Our Lives. Naperville, IL: Sourcebooks, Inc.

Fowler, James.1984. Becoming Adult, Becoming Christian: Adult Development and Christian Faith. San Francisco: Harper and Row.

Friedrich, Laura Dean Ford and Children and Youth Team.1997. Putting Children and their Families First: A Planning Handbook for Congregations. New York: General Board of Global Ministries, The United Methodist Church.

Gilligan, Carol. 1982. In a Different Voice. Cambridge: Harvard University Press.

Goodman, Ellen.1979. Turning Points. New York: Fawcett Crest Books.

Groome, Thomas H. 1998. Educating for Life: A Spiritual Vision for Every Teaching and Parent. Allen, TX: Thomas More.

Harris, Maria. 1988. Women and Teaching. New York: Paulist Press.

May, Rollo. 1975. The Courage to Create. NY: W.W. Norton \& Co.

Meyers, Patricia. 1994. Practicing God's Presence. Beaverton, OR: Creative Caring Communications.

Michael, Y., et al. 2000. Nurses Heath Study Newsletter 7: 5.

Moore, Allen J. 1991. Recovery of the teaching office: Insights from education. In By What Authority: A Conversation on Teaching Among United Methodists, eds. Elizabeth Box Price and Charles R. Foster. Nashville: Abingdon Press.

Palmer, Parker. 1998. The Courage to Teach, Exploring the Inner Landscape of a Teacher's Life. San Francisco: Jossey-Bass.

1998. Lecture at Portland State University (Feb. 4).

2000. Let Your Life Speak: Listening for the Voice of Vocation. San Francisco: Jossey-Bass. 
Sample, Tex.1990. U. S. Lifestyles and Mainline Churches, a Key to Reaching People in the 90s. Westminster/John Knox Press.

Taylor, S.E., Klein, L.C. et al. 2000. Female responses to stress: Tend-and-befriend, not fight-or-flight. Psychological Review 107:411-429.

Willhauck, Susan. 2001. Vertigo in Theological Education: A Study of Effective and Influential Teaching in the Washington Theological Consortium. (Unpublished). 